\title{
KONSTRUKSI SISTEM HUKUM INDONESIA
}

\author{
Emy Hajar Abra \\ Dosen Tetap Prodi Ilmu Hukum UNRIKA Batam \\ Email: my_87_hjf@yahoo.com
}

\section{$\underline{\text { ABSTRAK }}$}

System hukum suatu negara menentukan sumber hukum pertama dalam membuat sebuah kebijakan hukum, system hukum sendiri memiliki ciri khas tertentu walaupun kemudian antara beberapa system hukum kini mengalami perbedaan yang cukup tipis. Dalam hal mengetahui system hukum sebuah negara, maka yang dilakukan untuk menguatkan system hukum adalah dengan melihat system hukum negara lain. Perbandingan system hukum inilah yang kemudian dikaji untuk melihat pengelompokkan negara dalam keluarga system hukum nantinya.System hukum sejatinya menggambarkan bentuk hukum pada suatu negara, oleh karenanya ketika sebuah system hukum lahir dari stuktur, substansi dan kultur, maka system hukum pada suatu negara haruslah mencerminkan jati diri negara tersebut. Lahirnya system hukum dipengaruhi oleh banyak factor, seperti ekonomi, politik dan social.Artinya bahwa system hukum bisa jadi lahir karena factor-faktor eksternal, bukan nilai-nilai internal dari negara itu sendiri. Maka untuk menepis tipisnya persamaan dan perbedaan sebuah system hukum, akan lebih baik mencari system hukum yang sesuai dan sejalan dengan jati diri sebuah negara. Bukankah hukum adalah sebuah aturan yang mandiri. Bebas dari campur tangan dan pemaksaan. Hal inilah kemudian yang akan dikaji, bahwa ketika sebuah system hukum bernilai terbuka, maka system hukum harus memiliki konsistensi dengan nilai yang diakui dan dijunjung oleh masyarakat pada sebuah negara. Oleh karenanya perubahan sebuah system hukum menuju jati diri sebuah negara adalah keniscayaan dan tidak bisa dielakkan.Bahwa semakin tipisnya nilai perbedaan sebuah system hukum menjadi kritikan sebagai bahan kajian kelimuan hukum tersendiri yang patut diangkat.

Katakunci: system hukum, jati diri, negara.

\section{A. LATAR BELAKANG}

Sebelum berbicara mengenai system hukum, maka akan lebih tepatnya berbicara tentang system norma terlebih dahulu. Karena system hukum mempengaruhi tatanan putusan hukum sebuah negara, maka system hukum tidak akan pernah terlepas dengan "system norma", karena norma adalah bagian dari nilai-nilai hukum yang hidup sesuai pada pengakuan kehidupan bermasyarakat dan bernegara. Nilai-nilai pada normaitu hadir dan berkembang begitu saja disuatu negara tanpa keharusan untuk disahkan atau tidak. System Norma dapat menjadi salah satu bagian bahkan dasar dari sebuah system hukum. Maka 
System hukum adalah system norma. System dimaknai sebagai suatu kesatuan yang bersifat kompleks, yang terdiri dari bagian-bagian yang terhubung satu sama lain, sedangkan hukum menurut S.M. Amin, S.H adalah kumpulan peraturan yang terdiri dari norma dan sanksi, dengan tujuan mewujudkan ketertiban dalam pergaulan manusia.

Pada tahun 1900 M dalam hukum komparatif internasional pertama dikelompookkanlah klasifikasis system hukum ke dalam lima keluarga hukum: Romanistik, Jermanitik, Anglosaxon, Slavik, Islamik. Kemudian tahun 1977, Zweigert An Kotz membagi dalam delapan diantaranya: Romanistik, Jermanistik, Nordik, Camman Law, Sosialis, System Timur Jauh, Hukum Islam, Hukum Hindu. Pada 1978 David dan Brerley mengadopis dan menjadikannya sebagai Romano, Gemanik, Camman Law, Sosilaistik, Islamik, Hindu, Yahudi, Timur Jauh, Afrika Hitam. ${ }^{1}$

Sampai sekarang kita hanya mengenal empat sistem hukum yang masih bertahan dan populer, yakni: sistem hukum Eropa Continental, sistem hukum Anglo Saxon, sistem hukum adat dan sistem hukum islam. Prof. Dr. Jan Michiel Otto mengatakan bahwa perbedaan antara common law dan civil law di Eropa sudah semakin mengecil. Sistem hukum yang dianut Belanda berada di antara continental (civil law) dan common law, bahwa common law ada judge-made law (hakim yang membuat hukum), dan civil law adalah hukum `dibuat oleh legislator. Tapi di sistem Belanda, apa yang dipelajari ketika menjadi mahasiswa juga belajar banyak case law (kasus-kasus atau putusan pengadilan). Bagi beberapa orang Indonesia, ketika mereka mendapat beasiswa dan belajar hukum ke Australia, Inggris, Amerika Serikat, lalu mereka kembali mereka telah belajar banyak case law (putusan pengadilan). ${ }^{2}$ Artinya bahwa kini kelompok keluarga sistem hukum sudah lepas dari sejarah hadirnya sistem hukum itu sendiri, bahwa kini didapati sistem hukum yang satu pada negara lain justru juga menggunakan sistem hukum yang seharusnya bukan pada negara tersebut.

Sistem hukum islam tidak mudah ditemukan pada suatu Negara secara terang-terangan, namun sistem hukum ini dapat dikatakan bertahan dengan penggunaannya secara pelan dan tersembunyi. Bagaimana tidak, negara-negara didunia pada saat berada didalam penguasaan suatu negara, tapi negera penguasa tersebut secara tidak langsung memaksakan negara jajahannya untuk menggunakan sistem hukum mereka. Sekalipun sejarah, populasi serta

\footnotetext{
${ }^{1}$ Michael bogdan, pengantar perbandingan system hokum, nusamedia, bandung, 2015, hlm 100-102

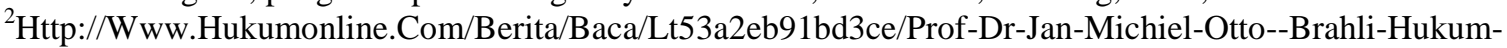
Indonesia-Harus-Sering-Kaji-Putusan
} 
hukum tidak tertulis yang digunakan adalah mengikuti ajaran penduduk atau adat suatu negara.

\section{B. METODE PENELITIAN}

Paradigma yang digunakan dalam kajian penulisan ini adalah Paradigma konstruktivisme. Konstruktivisme Paradigma ini memandang bahwa kenyataan itu hasil konstruksi atau bentukan dari manusia itu sendiri. Kenyataan itu bersifat ganda, dapat dibentuk, dan merupakan satu keutuhan. Kenyataan ada sebagai hasil bentukan dari kemampuan berpikir seseorang. Pengetahuan hasil bentukan manusia itu tidak bersifat tetap tetapi berkembang terus. Penelitian kualitatif berlandaskan paradigma konstruktivisme yang berpandangan bahwa pengetahuan itu bukan hanya merupakan hasil pengalaman terhadap fakta, tetapi juga merupakan hasil konstruksi pemikiran subjek yang diteliti. Pengenalan manusia terhadap realitas sosial berpusat pada subjek dan bukan pada objek, hal ini berarti bahwa ilmu pengetahuan bukan hasil pengalaman semata, tetapi merupakan juga hasil konstruksi oleh pemikiran. ${ }^{3}$

Sebagai penelitian yang bersifat deskriptif, maka analisa data yang digunakan adalah dengan cara analitis, cara analisis datanya disebut dengan cara deskriptif analitis. Deskriptif analitis adalah penelitian yang disamping memberikan gambaran secara rinci, menuliskan dan melaporkan suatu obyek atau suatu peristiwa juga akan mengambil kesimpulan umum dari masalah yang dibahas. ${ }^{4}$ Data yang terkumpul dari hasil penelitian ini dianalisa secara deskriptif kualitatif, yaitu data-data yang diperoleh dalam penelitian tersebut digambarkan dan ditata secara sistematis dalam wujud uraian-uraian kalimat yang diambil maknanya sebagai pernyataan atau kesimpulan. ${ }^{5}$

\section{PEMBAHASAN}

System hukum adalah sebuah ilmu hukum umum yang sifatnya cukup istimewa, hal ini karena system hukum adalah bagian dari sebuah tatanan dalam pembentukan sebuah negara dan aturan hukum yang ada didalamnya. Dalam hal mengenal system hukum maka kajian lain yang harus dilakukan untuk membandingkan dan mencari perbedaan serta persamaan pada negara lain, maka dilakukanlah ilmu perbandingan hukum khususnya mengenai system hukum. Secara umum sistem hukum atau tatanan hukum diartikan sebagai sebuah sistem dari

\footnotetext{
3 Arifin,Zainal. 2012.Penelitian Pendidikan Metode Dan Paradigma Baru.Bandung:Rosdakarya, Hlm 140 ${ }^{4}$ Soerjono Soekanto, Pengantar Penelitian Hukum, Ui Press, Jakarta, 2005, Hal 32.

${ }^{5}$ Rony Hanitijio Soemitro, Metodologi Penelitian Hukum Dan Juri Metri, Ghalia, Jakarta,1998, Hlm82
} 
keseluruhan kaidah-kaidah hukum dan bentuk penampilanya dalam aturan-aturan hukum. Sistem hukum merupakan suatu sistem terbuka yang harus mampu mengakomodasi perkembangan yang terjadi dalam masyarakat. ${ }^{6}$

System norma yang berlaku bagi manusia dalam bernegara sekurangnya terdiri dari empat unsur norma, yakni: norma moral, morna agama, norma etika, norma hukum. ${ }^{7}$ Faktor apa yang berpengaruh dan dianggap relevan bagi terbentuknya system hukum sangat ditentukan oleh nilai ideologis pengguna metode pembandingan itu sendiri. Contoh seorang marxis akan berpandangan secara tegas mengenai hubungan diantara system hukum produksi dan system hukum tersebut cendrung lebih mementingkan system ekonomi dari pada sosialis idealis.Seorang rasis akan percaya bahwa ras penduduklah yang menetukan segala aspek dalam kehidupan masyarakat. ${ }^{8}$

Faktor-faktor yang mempengaruhi dalam terbentuknya sebuah system hukum: ${ }^{9}$

1. System ekonomi

Kebutuhan akan aturan hukum yang melindungi terhadap praktik bisnis sebenarnya baru muncul ketika ekonomi pasar menyebabkan timbulnya pemusatan kekuatan ekonomi sampai taraf tertentu.

2. Ideologi dan system politik

System hukum sangat dipengaruhi oleh system politik negara.Ada hubungan kuat antara system politik dan system ekonomi suatu negara disatu isi dengan ideologi yang bertahta disisi yang lain.

3. Agama

Sikap dan keyakinan agama popolasi dapat berperan penting bagi system hukum.

Contoh sebuah negara yang didominasi umat Kristen akan kesulitan menerima poligami dan sementara muslim sebaliknya. Contoh lain tentang alkohol.

4. Sejarah dan geografi

System hukum terbentuk dibawah pengaruh kuat perkembangan sejarah negaranya.Pada negara-negara tertentu peninggalan darisebuah sejarahlah yang

\footnotetext{
${ }^{6}$ Sistem Hukum Indoneisa, Prinsip-Prinsip Dan Implementasi Hukum Di Indoensia, Ilham Bisri, Pt Raja Grafindo Persada, Jakarta, Tahun 2004, Hal 5

7 Sistem Hukum Indoneisa, Prinsip-Prinsip Dan Implementasi Hukum Di Indoensia, Ilham Bisri, Pt Raja Grafindo Persada, Jakarta, Tahun 2004, Hal 5

${ }^{8}$ Ibid, Hlm 80

${ }^{9}$ Michael Bogdan, Pengantar Penbandingan System Hukum, Bandung, Nusamedia, 2010, Hlm 88
} 
menentukansebuah system hukum yang berlaku bagi negaranya, walaupun akhirnya banyak adaptasi atau kearifan local setelah sekian lama dijajah.

5. Factor demografi

Umat manusia bisa dibagi menjadi beberapa ras dan etnis yang seringkali pula latar belakarang sejarahnya, walaupun keadaan yang demikian sudah berangsur dipulihkan dengan perpolitikan antara negara yang ikut mengahapusnya.

6. Factor kebetulan dan tak dikenal

Sama halnya dengan demografi hal ini sudah berangsur tidak diakui walaupun pada sejarahnya hukum kekeluargaan lahir atas inisiatif Napoleon, selain itu unsur-unsur tidak sengaja yang terjadi atas sebuah kepentingan membuat negara tersebut harus membuat kebijakan tersendiri.

Berbeda dengan sistem hukum Eropa Continental dan Anglo Saxon yang kini bisa dikatakan tipis perbedaannya. Indoneisa adalah pengguna system hukum campuran, walaupun pernyataan tersebut akan dibantah dengan mengatakan bahwa Indoensia hanya menggunakan system hukum eropa continental semata. System hukum Indonesia adalah system hukum dengan perpaduan dari tiga system hukum: Eropa Continental, system hukum adat, dan system hukum islam.

System hukum eropa continental adalah karena Indonesia dijajah belanda sangat lama yakni selama tiga setengah Abad, dari sebelum indoensia merdeka, belanda sudah memaksakan masyarakat untuk menggunakan system hukum belanda (sekalipun terdapat penggolakan hukum di nusantara), namun beberapa ketentuan undang undang peninggalan belanda itu ada yang akhirnya dirubah menjadi KUHPerdata dan pidana, dan lainnya sekalipun substansinya masih sedikit banyak menggunakan system hukum belanda

Sistem hukum adat justru adalah bagian dari sistem hukum yang lebih lama yakni dari masa awal sejarah tatanan kehidupan yang dibentuk hingga selama sistem hukum itu masih diakui dan dikembangkan. system hukum adat adalah system hukum terlama di indoensia bahkan jauh sebelum Indonesia merdeka, dia tumbuh dan berkembang dalam masyarakat, hukum yang dibuat, dihormati, dijaga dan dijadikan sebagai wewenang tertinggi. Ketika seseorang melakukan kesalahan maka hukum yang hidup dimasyarakatlah yang akan menghukumnya.

Kemudian sistem lain yang juga dirasa menarik dan mampu bertahan dengan ciri khususnya adalah sistem hukum islam. Tidak bisa dipungkiri islam mendominasi penduduk 
Indonesia, dengan demikian penduduk muslim tersebut bahkan sebelum Indonesia merdeka sudah patuh dan tunduk pada perintah dan larangan serta menjalankan hukum-hukum islam yang tertuang dalam Qur'an dan hadis. Sistem hukum islam adalah salah satu system hukum yang mempunyai ciri khusus karena berasal dari ajaran islam yang bersumber dari Allah dan Sunnah Rosul dan Ra`yu atau akal. System hukum ini bersumber dari ajaran agama yang dianggap paling mampu bertahan, sebelumnya terdapat beberpa system hukum agama lainnya seperti, system hukum hindu dan Kristen. Namun kini system hukum agama lainnya tidak mampu bertahan bahkan dibelahan Negara luar lainnya.

Lawrence M. Friedman mengemukakan tiga unsur sistem hukum, yaitu legal substance (substansi atau materi hukum), legal structure (kelembagaan hukum) dan legal culture (budaya hukum).Elemen pertama berupa keseluruhan aturan (kaidah) dan asas hukum.Elemen kedua menunjuk pada keseluruhan organisasi, lembaga-lembaga dan pejabatpejabatnya, yang meliputi badan-badan legislatif, eksekutif, dan yudikatif dengan aparataparatnya seperti birokrasi pemerintahan, pengadilan, kejaksaan, kepolisian, dan dunia profesi seperti advokatur dan kenotariatan.Sedangkan unsur atau elemen ketiga merupakan unsur aktual yang menunjuk pada keseluruhan putusan ataupun perilaku yang berkaitan dengan unsur pertama. ${ }^{10}$

Ada beberapa alasan kenapa system hukum dapat berubah, yakni:

1. Perubahan dan pergeseran sebuah nilai ideology suatu bangsa

2. Keinginan pengusa dalam membentuk suatu tatanan bernegara

3. Keinginan politik internasional atas suatu negara

4. Keinginan kuat masyarakat karena faktor ekonomi, politik, social dan lainnya

Gambia adalah satu negara yang secara terbuka mampu menerima bahkan melaksanakan system hukum Negara yang menguasainnya, begitupun ketika mengalami perubahan, Gambia mampu mengikuti perubahan tersebut. Gambia memiliki latar belakang yang hampir sama dengan Turki, namun memiliki sejarah dan sistem hukum yang berbeda. Gambia cukup lama dijajah oleh Negara Inggris, kemudian gambia menyerah dan mengikuti kemauan Inggris agar dimasukkan dalam negara persemakmuran Inggris dengan kepala Negara adalah Ratu Elizabet, maka secara otomatis Gambia tunduk pada sistem hukum anglo

\footnotetext{
${ }^{10}$ Lawrence M. Friedman, Sistem Hukum, Nusa Media, Bandung, 2013
} 
saxon. Sistem hukum inggris di Gambia adalah bagian dari sistem hukum yang dijalankan atas prakarsa politik kekuasaan semata.

Namun kini Gambia berani untuk mendeklarasikan negaranya sebagai negara islam dan juga berani menghentikan system colonial dalam negaranya. Pada pertengan Desember 2015 lalu, Presiden Gambia Yahya Jammeh mendeklarasikan negara dengan mayoritas Muslim yang dipimpinnya sebagai republik Islam, dengan mengatakan langkah tersebut dilakukan untuk memutuskan ikatan dengan masa colonial. ${ }^{11}$

System hukum Turki sebelumnya menggunakan eropa continental, beberapa hukum dipaksakan untuk menggunakan system hukum eropa dengan mengadopsi hukum swiss dan italia. Hal tersebut cukup berpengaruh ketika turki menjadikan negaranya sebagai negara islam sekuler, namun kini system hukum eropa continental tersebut secara perlahan mulai disingkirkan dengan menghidupakan kembali nilai hukum islam dan mengarahkan system hukum turki ke system hukum islam seperti sediakala. UUD beberapakali di amandemen, UU tentang pelarangan ajaran islam dihapuskan, sejak Turki dipimpin oleh Recep Tayyip Erdogan yang menggantikan system pemerintahan Mustafa Kemal yang sekuler.

Indonesia memiliki mayoritas penduduk muslim sama seperti Turki dan Gambia. Namun yang membedakan adalah bukan berarti Indonesia memiliki keberanian yang sama dengan Gambia dan Turki. Hukum Indonesia berdasar pancasila, maka keragaman adalah keniscayaan di indoensia. Sistem hukum Indonesia adalah campuran dari sistem hukum adat, islam dan Eropa Continental, artinya Indoensia menganulir tiga system hukum pada satu negara.

Sistem hukum islam bisa didapati pada beberapa undang undang yang menganulis nilai islam sepeti pada undang undang zakat, perkawinan, penyelenggaraan ibadah haji, dan undang undang lainnya serta satu kompilasi hukum islam yang wajib dijadikan sebagai rujukan bagi seluruh pengadilan agama di seluruh wilayah Indonesia.

Sedangakan pada sistem hukum adat, hukum indoensia tidak mampu melawan ketika suatu kasus yang terjadi ditengah masyarakat hukum adat, kemudian oleh lembaga adat dihukum dengan menggunakan hukum adat yakni hukum yang berlaku dan dipertahankan oleh masyarakat adat tersebut. Maka negara tidak patut menghargai keputusan kepala adat setempat. Hal ini bisa dilihat pada adanya masyarakat samin, dayak dan lainnya adalah bukti

${ }^{11}$ http://www.bbc.com/indonesia/dunia/2015/12/151212_dunia_gambia, diakses pada 27 Mei 2016 
nyata bahwa negara menghargai dan menghormati kehidupan sistem hukum adat di Indoensia.

Ketua Mahkamah Agung Amerika Serikat ke 14 Earl Warren (1891-1974) pernah menjelaskan dengan lugas di depan peserta pertemuan ahli-ahli hukum dunia (World Peace Through Law) 1963 di Athena Yunani bahwa: ${ }^{12}$

“ di dinding ruang tempat kami menyidangkan perkara-perkara yang di putus oleh Mahkamah Agung, terpahat lukisan/lambang para tokoh pembangun hukum dunia. Kami susun sedemikan rupa, sehingga di sebelah kiri dinding ada nama-nama seperti Menes (mesir), Hammurabi (Babylon), Musa dan Salomon (Israel), Lycurgus, Solon dan Draco (Yunani), Confius (Cina) dan Augustus (Roma) sebagai sembilan tokoh pembangun hukum yang hidup sebelum masehi. Sedangkan nama-nama seperti Justisianus (Roma), Muhammad (Islam), Charlemagne (Jerman), King Jhon Dan Black Stone (Inggris), Saint Louist dan Napoleon (Prancis), Hugo Grotius (Belanda) dan Marshall (Amerika Serikat) berada disebelah kanannya yang diletakan sebagai sembilan tokoh pembangun hukum dunia yang hidup sesudah masehi. Dan selalu setiap ketika kami bersidang termasuk ketika mendengarkan argumen-argumen para pengacara dan memutuskan perkara-perkara, tokohtokoh pembangun hukum dunia itu seakan-akan memandang kebawah sedang memperhatikan kami dan tak jarang kami yang menengadah ke atas kepada mereka untuk mencari ilham dalam memutus perkara.

\section{PENUTUP}

Maka dari pembahasan diatas, penulismembuat kesimpulan bahwa:

1. Negara Turki, Gambia bahkan Indonesia adalah hanya beberapa negara yang menjalankan prinsip sistem hukum islam sebagai sistem hukum pada negaranya masing-masing, walaupun sistem hukum yang dilakukan adalah tidak secara revolutif dan menyeluruh.

2. Sistem hukum islam adalah salah satu sistem hukum yang diakui bidang keilmuan, sehingga oleh para pemikir barat kemudian dimaksukkan dalam

\footnotetext{
12 Busthanul Arifin, Hukum Pidana (Islam) Dalam Lintasan Sejarah, Dalam Pidana Islam Di Indonesia: Peluang, Prospek Dan Tantangan, Pustaka Firdaus, Jakarta, 2001, Hlm 34
} 
salah satu keluaga sistem hukum dunia yang bertahan lama, yang juga digunakan dibelahan dunia.

3. Sistem hukum yang dijalankan oleh sebuah negara sepatutnya adalah sistem hukum yang dijalankan bukan karena hasil penjajahan, persemakmuran negara-negara, perpolitikan, bahkan hanya karena kepopuleran sebuah sistem hukum semata. Namuan sejatinya sistem hukum yang dijalankan adalah sistem hukum yang tumbuh, berkembang dan sesuai dengan kebutuhan, ideology dan keinganan serta kebahagiaan tatanan kehidupan masyarakat pada suatu negara, dengan begitu maka sistem hukum adalah bagian dari jati diri sebuah negara.

\section{REFERENCES}

Busthanul Arifin, Hukum Pidana (Islam) Dalam Lintasan Sejarah, Dalam Pidana Islam Di Indonesia: Peluang, Prospek Dan Tantangan, Pustaka Firdaus, Jakarta, 2001 
Arifin,Zainal. 2012.Penelitian Pendidikan Metode Dan Paradigma Baru.Bandung:Rosdakarya

Soerjono Soekanto, Pengantar Penelitian Hukum, Ui Press, Jakarta, 2005

Sistem Hukum Indoneisa, Prinsip-Prinsip Dan Implementasi Hukum Di Indoensia, Ilham Bisri, Pt Raja Grafindo Persada, Jakarta, Tahun 2004

Sistem Hukum Indoneisa, Prinsip-Prinsip Dan Implementasi Hukum Di Indoensia, Ilham Bisri, Pt Raja Grafindo Persada, Jakarta, Tahun 2004

Michael Bogdan, Pengantar Penbandingan System Hukum, Bandung, Nusamedia, 2010

Lawrence M. Friedman, Sistem Hukum, Nusa Media, Bandung, 2013

Rony Hanitijio Soemitro, Metodologi Penelitian Hukum Dan Juri Metri, Ghalia, Jakarta,1998

Http://Www.Hukumonline.Com/Berita/Baca/Lt53a2eb91bd3ce/Prof-Dr-Jan-Michiel-Otto--

Brahli-Hukum-Indonesia-Harus-Sering-Kaji-Putusan

http://www.bbc.com/indonesia/dunia/2015/12/151212_dunia_gambia, diakses pada 27 Mei 2016 